\title{
$60^{\circ}$ Aniversario de la Revista Argentina de Cirugía Revista Argentina de Cirugía 60th anniversary
}

\author{
Roberto A. Cerutti*
}

Es con gran orgullo que celebramos el $60^{\circ}$ aniversario de la Revista Argentina de Cirugía, publicación que remonta sus inicios al año 1960.

Por entonces, la Asociación Argentina de Cirugía $(A A C)$ dispuso la creación de una revista oficial, que congregara los trabajos e investigaciones en el campo de la cirugía. Este proyecto fue evaluado por un grupo de prestigiosos cirujanos que se comprometieron con la idea, trabajaron arduamente e iniciaron su publicación.

Esta iniciativa, muy brillante por cierto, permitió que los cirujanos de todo el país tuvieran a su disposición una fuente de consulta de los mejores trabajos científicos de investigación referidos a las especialidades quirúrgicas.

La revista se publicó mensualmente, conformando dos volúmenes semestrales, cuyo último número agregaba un índice de los autores y las publicaciones, facilitando la búsqueda e identificación de los temas.

Por ello se logró contar con una publicación de consulta, tanto para profesionales en formación como en actividad, para que pudieran acceder a las novedades en el campo de la investigación, así como también a las comunicaciones presentadas por otras sociedades quirúrgicas del país que tuvieran particular interés.

Se caracterizó por realizar una cuidadosa selección de los trabajos para publicar, y se evaluó minucio- samente la presentación, la redacción de los artículos y la claridad de los resúmenes.

La edición actual con formato Online y una frecuencia trimestral, con acceso gratuito y en idioma castellano e inglés, posibilitó una mayor difusión, logrando ser una revista de consulta en otros ámbitos académicos.

Otro logro indiscutido de su compromiso en alcanzar nuevas metas lo concretó en los últimos años, al reincorporarse a SciELO (Scientific Electronic Library Online), con lo que accede al mayor nivel de indización en el ámbito iberoamericano.

Es de suma importancia el aporte permanente de los cirujanos y su compromiso en la presentación de trabajos de buen nivel académico, para continuar sosteniendo la excelencia de la Revista Argentina de Cirugía.

Aspiramos en el futuro, con el esfuerzo de todos, a avanzar hacia mejoras que la hagan cada vez más importante y reconocida en los círculos quirúrgicos del país y el extranjero.

Como presidente de la AAC y en representación de su Comisión Directiva, felicito y quiero agradecer a los actuales responsables de la Revista, así como también a todo su staff por la dedicación y el compromiso que ponen en esta importantísima tarea.

\section{—ENGLISH VERSION}

It is with great pride that we celebrate the 60th anniversary of the Revista Argentina de Cirugía, a journal that dates back to 1960 .

At that time,the Asociación Argentina de Cirugía (AAC) decided to create an official journal, which would gather the works and research in the field of surgery. This project was evaluated by a group of prestigious surgeons who committed themselves to the idea, worked hard and started its publication.

This very brilliant initiative allowed surgeons nationwide to access the best scientific research papers on surgical specialties.

The journal was published monthly, constituting two biannual volumes; the last issue included an index of the authors and publications, simplifying the search and identification of the topics.

Therefore, professionals and trainees were able to access the latest news in research, as well as the papers presented by other national surgical societies of particular interest.

The papers submitted for publication were carefully selected, and the presentation and writing of the articles and clarity of the abstracts were thoroughly evaluated.

At present, the journal is published online every three months with free access in Spanish and English, resulting in wider diffusion and positioning it as a reference journal in other academic fields.

Another undisputed achievement of its commitment to reaching new goals occurred in the last 
few years when the journal was indexed again by SciELO (Scientific Electronic Library Online), gaining access the most comprehensive index of Ibero-American journals.

The permanent contribution of surgeons and their commitment to the presentation of articles of high academic level is of utmost importance to further support the excellence of the Revista Argentina de Cirugía.
In the future, with everybody's contribution, we hope to move forward towards improvements that will make the journal more prominent and recognized in the local and international surgical environments.

As President of the AAC and on behalf of its Board of Directors, I congratulate and thank the current heads of the Journal, as well as all the staff for their dedication and commitment to this very important task. 


\section{PROPOSITOS Y ANHELOS}

La Recista Argentina de Cirugía nace con el primordial deseo de ofrecer a los cirujanos argentinos un órgano especializado que difunda su labor (que tal fue el propósito con el que la Asociación Argentina de Cirugía la creó y la erigio su publicación oficial). Sus páginas están abiertas a todos los médicos, connacionales o extranjeros, cirujanos o no, que tengan algo de interés que decir, relacionado con la cirugía.

Será norma invariable de la Revista Argentina de Cirugía seleccionar rigurosamente los trabajos que publique; trabajos cuyo valor procurará destacar, por otra parte, mediante una presentación adecuada. Como también pretende camplir una función educativa, cuidará especialmente en sus artículos la pureza de la redacción, la exactitud y el debido ordenamiento de las referencias bibliográficas y la precisión de los resúmenes. $Y$, al mismo tiempo, tratará así, de facilitar la lectura, simplificar las consultas y ganar el respeto de sus lectores.

Además de los trabajos inéditos que formarán el cuerpo principal de cada número, incluirá comunicaciones presentadas en sociedades quirúrgicas del país, yue, ajuicio del Comité de Redacción, tengan particular interés; incluirá asimismo actualizaciones originales, firmadas por autores de capacidad reconocida. Quiere, de esta manera, ofrecer a los cirujanos (especialmente a los que están en formación y a aquellos que por actuar lejos de los grandes centros no tienen acceso a muchas revistas médicas) una visión panorámica y moderna de variados temas de cirugía. También registrará, en un noticiario, la actividad quirúrgica nacional y aquella de otros países que pueda importar a los cirujanos argentinos. Ocasionalmente, publicará trabajos de casuística y notas de técnica. Y, en el futuro, de acuerdo con lo que la experiencia enseñe y con lo que los lectores sugieran, añadirá nuevas secciones.

La Revista Argentina de Cirugía aparecerá mensualmente. Los doce números anuales formarán dos volúmenes, uno por semestre. El último número de cada volumen llevará un Fichero Bibliográfico Argentino, en el que, debidamente agrupados, figurarán los títulos y los autores de los trabajos quirúrgicos o relacionados con la cirugía que se publiquen en el país. Se divulgará también; así, la labor de los cirujanos argentinos y se facilitará la consulta de la producción cernácula.

En éste su primer número, la Revista Argentina de Cirugía saluda a todo el periodismo nacional, al que se siente muy honrada de incorporarse. $Y$, en forma muy singular, saluda a las publicaciones médicas, con las que desea contraer estrechos vínculos amistosos.

Si logra cumplir con sus designios y colmar sus aspiraciones, la Revista Argentina de Cirugía será el vocero que la cirugía nacional merece y necesita y, constituirá, por lo tanto, un órgano obligado de consulta. Confía, para alcanzar el ideal que persigue, obtener la adhesión y la ayuda de sus lectores, quienes, seguramente, han de compartir sus anhelos.

El Director y los Miembros del Comité de Redacción agradecen a la Asociación Argentina de Cirugía la confianza que en ellos ha depositado y se comprometen a poner todo su empeño y entusiasmo para que la Revista Argentina de Cirugía sea, para la entidad que la creó, un permanente motivo de satisfacción y de orgullo. Agradecen también a la Editorial Panamericana su generoso apoyo, sin el que no hubiera sido posible cristalizar esta iniciativa.

Dres. Andrés A. Santas, Miguel Correa Iturraspe, Alfredo Llambías, Juan R. Michans y Rodolfo Varela Chilese.

$1^{\text {o. }}$ de julio de 1960

Facsímil del editorial original del Vol 1 N1 - julio 1960 Rev Argent Cirug. 